\title{
Cases of melanism in mountain hare (Lepus timidus) in Yakutia
}

\author{
Gennady G. Boeskorov*, Vladimir N. Vinokurov, \\ Marina V. Shchelchkova \& Vladislav G. Boeskorov
}

\begin{abstract}
Cases of melanism in the mountain hare Lepus timidus in the territory of Yakutia were analyzed. The highest frequency of this rare phenomenon was observed in the basin of the Vilyuy River, with at least nine cases over the last 50 years. It was proposed that this phenomenon was the result of increased mutagenesis in this territory, due to consequence of the features of the natural geochemical background and anthropogenic pollution.
\end{abstract}

How to cite this article: Boeskorov G.G., Vinokurov V.N., Shchelchkova M.V., Boeskorov V.G. 2020. Cases of melanism in mountain hare (Lepus timidus) in Yakutia // Russian J. Theriol. Vol.19. No.1. P.79-84. doi: 10.15298/rusjtheriol.19.1.08.

KEY WORDS: melanism, mountain hare, Lepus timidus, mutagenesis, Yakutia.

Gennady G. Boeskorov [gboeskorov@mail.ru], Diamond and Precious Metals Geology Institute, Siberian Branch of Russian Academy of Sciences, Prospect Lenina 39, Yakutsk 677980, Russia; Mammoth Fauna Study Department, Yakutia Academy of Sciences, Prospect Lenina 39, Yakutsk677007, Russia; Vladimir N. Vinokurov [vnvin@inbox.ru], M.K. Ammosov's North-Eastern Federal University, Natural Sciences Institute, Kulakovskogo str. 48, Yakutsk 677013, Russia; Marina V. Shchelchkova [mar-shchelchkova@yandex.ru], M.K. Ammosov's North-Eastern Federal University, Natural Sciences Institute, Kulakovskogo str. 48, Yakutsk677013, Russia; Vladislav G. Boeskorov [gboeskorov@mail. ru], Mammoth Fauna Study Department, Yakutia Academy of Sciences, Prospect Lenina 39, Yakutsk 677007, Russia.

\section{Случаи меланизма у зайца-беляка (Lepus timidus) в Якутии}

\section{Г.Г. Боескоров*, В.Н. Винокуров, М.В. Щелчкова, В.Г. Боескоров}

РЕЗЮМЕ. В статье рассмотрены случаи меланизма у зайца-беляка Lepus timidus на территории Якутии. Наибольшая частота встречаемости этого редкого явления отмечена у данного вида в бассейне р. Вилюй, по крайней мере, 9 случаев за последние 50 лет. Предполагается, что наибольшая встречаемость зайцев-меланистов в бассейне р. Вилюй связана с повышенным мутагенезом на данной территории, являющимся следствием особенностей естественного геохимического фона и антропогенного загрязнения.

КЛЮЧЕВЫЕ СЛОВА: меланизм, заяц-беляк, Lepus timidus, мутагенез, Якутия.

\section{Introduction}

Melanism is found in many animal species. It is caused by a buildup of melanin pigment, producing abnormal black or dark brown coloration of the outer layers, such as skin and hair. Melanistic individuals are usually quite rare in nature, most often the result of a recessive mutation. However, there are also several examples where melanistic coloring of animals is adaptive and supported by natural selection, becoming fixed in separate populations and acquiring features of adaptive polymorphism. These examples include the phenomenon of industrial melanism in birch moth Biston betularia Linnaeus, 1758 (Kettlewell, 1955; Majerus, 2009), an increased number of tropical cats that are melanistic (Ulmer, 1941; Majerus, 1998; Eizirik et al., 2003). Leopards Panthera pardus Linnaeus, 1758

\footnotetext{
* Corresponding author
}

and jaguars $P$. onca Linnaeus, 1758, which manifest melanism, are both referred to as black panthers.

An example of the substantial spread of a mutation that leads to melanism among felines is found in the leopard population in Malaysia, where about $50 \%$ of the animals are black. In general, among large cats, melanism is usually more common in those populations that live in dense forests. With the reduced light, dark animals are less noticeable in such environments compared to open areas, giving them a selective advantage in hunting and survival (Kawanishi et al., 2010). A high frequency of occurrence of melanists is also noted among some species of pikas and hares. Black pika, often found in southern China (Yunnan), is sympatric with Forrest's pika Ochotona forrest $i$ Thomas, 1923, and has been described as a separate species, $O$. nigritia Gong et al., 2000. The black Manchurian hare Lepus melainus Li \& Luo, 1979 is sympatric with Manchurian hare L. mandshuricus 
Radde, 1861. The species validity of these black forms has been questioned, and detailed morphological analysis has shown that $O$. nigritia and L. melainus are melanistic individuals of the Forrest's pika and Manchurian hare, respectively (Ge et al., 2012).

In other cases, an increase in the number of melanists is not associated with the adaptive value of dark coloration; however, it may correlate with some physiological feature that helps them survive in certain conditions. This phenomenon has been observed in the common brushtail possum Trichosurus vulpecula Kerr, 1792 (Pearson, 1938), common hamster Cricetus cricetus Linnaeus, 1758 (Gershenzon, 1946) and water vole Arvicola terrestris Linnaeus, 1758 (Evsikov et al., 1997; Bazhan et al., 1999, 2000).

In some poikilothermic animals, for example, insects (two-spotted ladybeetle Adalia bipunctata Linnaeus, 1758; Timofeeff-Ressovsky, 1940), and reptiles, melanistic colouration provides a more efficient use of solar radiation, increasing the length of their active periods (Clusella Trullas et al., 2008; Tuniyev et al., 2009). In addition, an increase in the number of melanists can be explained by increased mutagenesis, due to the influence of environmental geochemical conditions, including anthropogenic anomalies (Sharygin \& Popov, 2003; Kukushkin, 2009), genetic drift and splitting of recessive alleles due to isolation and marginalisation of populations (Capula et al., 2008; Blanke, 2010), or a combination of these factors (Doronin, 2012).

In general, there is a trend towards a relative increase in the number of melanists in the southern regions of Asia. In the north, in Siberia, melanists are rarer. Also, previous reports of mammalian melanists in the territory of Yakutia are limited and unsystematic. This also applies to the mountain hare Lepus timidus Linnaeus, 1758, one of the most important and widespread game species. This species has a pronounced adaptive seasonal dimorphism in fur coloration, having a snow white pelage in winter. It might be suggested that melanistic forms should not be supported by selection and survive in nature in the north. Nevertheless, Robert Maak, the well-known explorer of Siberia and the Far East, who explored the basin of the Vilyuy River, wrote that he "...brought from Vilyuy two skins of the black variety ... of mountain hare, ... representing there, however, a great rarity..." (Maak, 1886; p. 145). Earlier, in a preliminary publication, we reported on some cases of melanism in mountain hares of Yakutia (Vinokurov et al., 2017). In this current study, we analyzed all available sources and conducted a separate assessment of this issue.

\section{Material and methods}

To obtain information on melanists among mountain hares in the territory of Yakutia, we collected survey data from zoologists and hunters. In addition, the authors (BGG, VVN) analyzed their own perennial data from shooting, catching, and observations of the hares. Stuffed hares were also assessed, which were stored in various museums of Yakutia: the E.M. Yaroslavsky's Yakutsk
State United Museum of History and Culture of the Peoples of the North, Yakutsk City; local museums in Tiksi, Chokurdakh, Chersky, Pokrovsk, Tit-Ary and Neryungri villages and towns; the Museum of the Yana Geological Party, Batagay settlement, Verkhoyansk District; the B.N. Andreev's Elgyay Regional MuseumEcological Centre (short abbreviation - ERMEC), Elgyay village, Suntarsky District; and the Zoological Museum of the M.K. Ammosov's North-Eastern Federal University (ZM NEFU), Yakutsk City.

At ZM NEFU, with the efforts of taxidermist A.D. Makarov, various stuffed mammals with color anomalies were collected and mounted, including two melanistic L. timidus.

\section{Results}

The study of materials in various museums of Yakutia, as well as personal data and information from the regional press, allowed us to collect information on melanist hares registered in Yakutia over at least the past 50 years.

In the late 1950 s and early 1960 s, the skin of one of two single-outlet black melanist hares from the Megino-Kangalassky District (Dr. Yu.V. Labutin, pers. comm.) was brought to the Institute of Biology, Yakutsk. Subsequently, a stuffed animal was made from this skin.

In 1978, a melanist hare was caught by hunter A.R. Ksenophontov in the valley of the Tyukian River, in the vicinity of the Botulu Village, Verkhnevilyuisky District. Until recently, it was kept as a mounted specimen in the school museum of this village.

Three melanist hares were also hunted in the vicinity of Tuoydakh village in the Suntarsky District on the following dates: October 2002 by A.K. Alexeyev, December 22, 2002 by V.D. Grigoriev (Fig. 1), and December 2013 by V.A.Prokopyev (Fig. 2). The dead hares were sent to the Department of Biological Resources of the Ministry of Nature Protection of Yakutia. Taxidermy mounts were made from the hares killed by V.D. Grigoriev and V.A. Prokopyev, which were exhibited in the ZM NEFU. Thus, at least three melanist hares had been hunted in the same area over 11 years. As such, this color form of hare might be found regularly in this area.

Information about melanist hares was also received in 2003. In the local newspaper "Suntaar Sonunnar" (=Suntar News), No. 109, 25.09. 2003, Ivan Chagdinsky reported on a black hare being hunted in the vicinity of Neruktay. It was also noted in this article that two other melanist hares were hunted in 2002 in the Khadan and Ilimnir localities of the Suntarsky District. A mount of one of these hares was available in the ERMEC.

In the early $2000 \mathrm{~s}$, there were two reports of melanist hares being caught in the Nyurbinsky District (Vinokurov et al., 2017). In December 2012, a melanist hare was hunted in the Kobyai District. It was an adult overwintered individual with a body weight of about $2 \mathrm{~kg}$. 


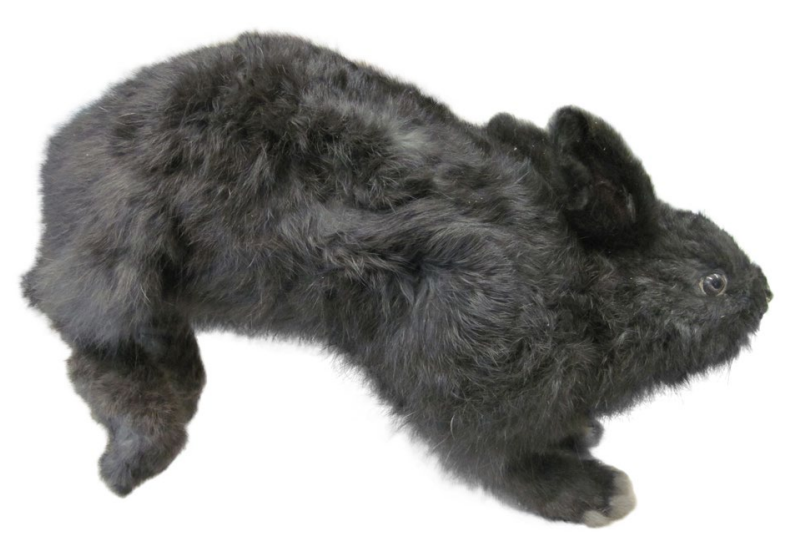

Fig. 1. Stuffed melanist mountain hare Lepus timidus from the Suntarsky District, hunted in December 2002. Specimen from ZM NEFU.

We studied two melanist hares from the area around Tuoydakh village. The first, hunted in December 2002, was an adult male of more than one year of age, which had apparently overwintered, and had a body length of $58 \mathrm{~cm}$, a hindfoot length of $15 \mathrm{~cm}$ and an ear length of $6.5 \mathrm{~cm}$. The second hare, caught in December 2013, was a young male with a body length of $47 \mathrm{~cm}$, hindfoot length of $14.5 \mathrm{~cm}$, ear length of $7.5 \mathrm{~cm}$ and body weight of about $2 \mathrm{~kg}$. Both individuals showed healthy development. The fur on these hares was even, thick, fluffy, and shiny. Their noses and lips were black, and their ears were normal. The hair color on the upper lips was black-gray, while the vibrissae were black. The ears were densely covered with monotonous black hair, and underfur was black. Hair color on the head was black, with black-gray colored hair around the eyes. The iris of the eye was a normal brown color. The neck and chest areas were black. The fur on the body (on the shoulder blades, shoulders, back, rump, sides, groin, and abdomen) was monotonously black, with the underfur being thick and black-gray. Tails were black, with black and gray underfur. The front and posterior legs were black on the superior portion, and blond and ash-gray on the inferior part. The transition from black to ash-gray was sharp. The claws were dark. The average height of hair on the back was: guide, $4.5 \mathrm{~cm}$; guard, $3.5 \mathrm{~cm}$; and down, 2.5-3.0 cm (Vinokurov et al., 2017).

\section{Discussion}

Over the past 50 years, at least 12 cases of melanist hares have been recorded in the territory of Yakutia, all within the central and western part of Yakutia, the territory inhabited by the subspecies L. timidus gichiganus J. Allen, 1903 (Ognev, 1940; Averianov, 1994; Hoffmann \& Smith, 2005). Of these, nine specimens were hunted in the middle reaches of the Vilyuy River basin (Fig. 3). Besides, consideration should be given to the discovery in this region of two hares of the "black variety" by R. Maak in the mid-19th century (Maak, 1886). As such, the reasonably regular

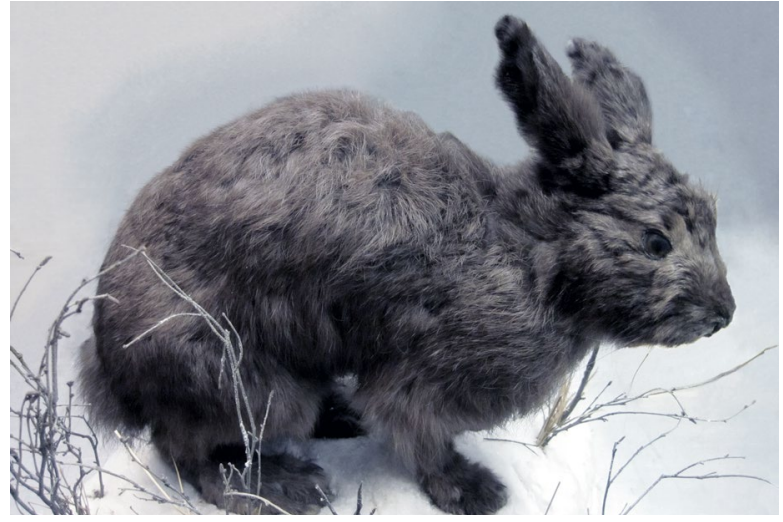

Fig. 2. Stuffed melanist mountain hare Lepus timidus from the Suntarsky District, hunted in December 2013. Specimen from ZM NEFU.

occurrence of melanist hares in the Vilyuy group of districts (Verkhnevilyuisky, Suntarsky, and Nyurbinsky Districts) suggested their occurrence was more than just sporadic. Indeed, it has been suggested that the fairly regular occurrence of melanist hares in the Vilyuy River basin indicated that the melanistic coloring might have some selective advantages (Vinokurov et al., 2017). For example, during autumn hunting, before snowfall, dark hares are harder to see than those that are white, potentially giving the melanists a survival advantage. However, there was a lack of reports of melanistic hares in southern and northern Yakutia, which also regularly has autumn hunting.

The Vilyuy River and its adjacent territories belong to environmentally unfavorable areas of Yakutia. They are natural but abnormal geochemical zones due to an increased background of rare and heavy elements, including those that are especially toxic and mutagenic: arsenic, mercury, lead, antimony, thallium, and radioactive strontium. Pollution of the Vilyuy River basin by toxic elements increased significantly in the second half of the 20th century as a result of intensive development of diamond mining and energy industries, as well as underground nuclear explosions in the 1970s and 1980s, which resulted in polycomponent pollution zones (Burtsev \& Kolodeznikov, 1996; Marshintsev \& Yagnishev, 2008). The high occurrence of melanist hares in the basin of the Vilyuy River basin may be associated with an increased mutagenic background of both natural and anthropogenic origin. However, long before the industrial development of this region of Yakutia, in the mid-19th century, there were recorded cases of melanistic mountain hares and Siberian chipmunk Eutamias sibiricus (Laxmann, 1769) in the Vilyuy River basin, Suntarsky District (Maak, 1886). Also, similar cases in chipmunks were described in the Suntarsky District and in the 1930s (ERMEC data). Even so, in the past 50 years, the occurrence of melanist hares has increased in this area, which was consistent with an increase in anthropogenic pollution. 

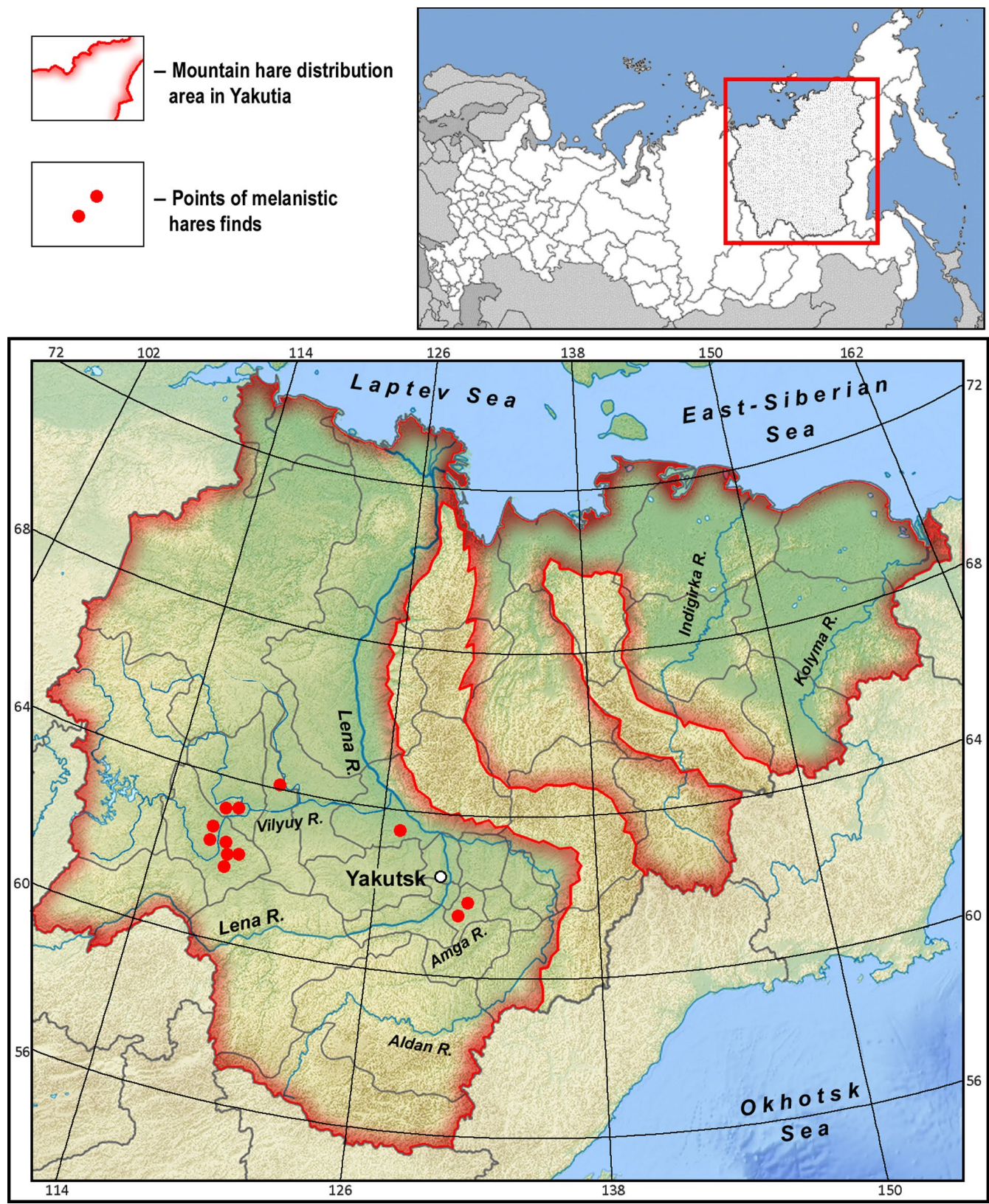

Fig. 3. Distribution of the mountain hare Lepus timidus in the territory of Yakutia (after Tavrovsky et al., 1971) and the locations of finds of melanist hares from the mid 20th century to the beginning of the 21 st century.

Other examples confirmed this hypothesis. A rare case of melanism was found in the bank vole Myodes glareolus Schreber, 1780, in the zone of radioactive contamination after the accident at the Chernobyl nuclear power station (Krapivko, 1999). Apparently, an increased mutagenic background caused by high seismic activity could have caused the appearance of melanists in two systematically distant species, the northern pika O. hyperborea Pallas, 1811 (Malyshev, 2015) and the northern red-backed vole Myodes rutilus Pallas, 1779 in the Upper Angara River structural basin, Northern Transbaikalia (Malyshev, 2010).
Cases of melanism in the mountain hare have been rarely observed in other regions, in Moscow (Mutsetoni, 1987) and Tyumen (Gashev \& Parfenov, 2006) regions. Several cases of melanists in the European hare L. europaeus (Pallas, 1778) have also been recorded in Ukraine (Galaka, 1967). Melanism in these species of hares might be caused by a rare recessive allele (or alleles).

In some mammalian species, it has been indicated that melanistic individuals might have certain ethological and physiological advantages that allow them to successfully compete against individuals with wild-type coloring, such as: increased caution (red fox Vulpes vulpes 
Linnaeus, 1758; Heptner et al., 1967); possible resistance to viral infections and faster reactions (domestic cat Felis catus Linnaeus, 1758; Seidensticker \& Lumpkin, 2006); and cold tolerance (common hamster; Gershenzon, 1946; and common brushtail possum; Pearson, 1938). Perhaps melanism in mountain hares also provides some advantage, which allows them to overwinter without a typical cryptic winter coloration of the fur in Yakutia conditions with an extended snow cover.

The phenomenon of melanism in hares in the territory of Yakutia requires further in-depth studies, involving both environmental data and genetic research.

ACKNOWLEDGMENTS. The authors thank taxidermist of the Zoological Museum of the NEFU Mr. A.D. Makarov for assistance in work and providing information on the hares-melanists. The authors would like to express their gratitude to the Proof-Reading-Service. com LTD, United Kingdom, for linguistic improvements.

This research was conducted within the frameworks of the next scientific programs: Ministry of Higher Education and Science of Russia task \#37.7935.2017/6.7; project 0381-2019-0002 of Institute of Diamond and Precious Metals Geology SB RAS.

The authors thank Mr. Alexander Stepanov for help in making Figure 3 and improving Figures 1 and 2.

\section{References}

Averianov A.O. 1994. [Systematics and evolution of hares of the genus Lepus (Lagomorpha, Leporidae) of the Palaearctic] // Abstract of PhD Dissertation in Zoology. Saint Petersburg: Zoological Institute RAS. 24 p. [in Russian].

Bazhan N.M., Makarova E.N. \& Yakovleva T.V. 2000. [Natural selection and the maintenance of coat-color polymorphism in the water vole populations] // Kolchanov N. et al. (eds.). [Biodiversity and Dynamics of Ecosystems in North Eurasia]. Novosibirsk: Nauka. P.35-38 [in Russian].

Bazhan N.M., Yakovleva T.V. \& Makarova E.N. 1999. Agouti locus may influence reproduction under food deprivation in the water vole (Arvicola terrestris) // Journal of Experimental Zoology. Vol.283. No.6. P.573-579.

Blanke I. 2010. Die Zauneidechse // Zeitschrift für Feldherpetologie. No.7. S.1-176.

Burtsev I.S. \& Kolodeznikov E.N. 1996. [Radiation situation at the objects of emergency underground nuclear explosions "Kraton-3" and "Crystal"] // Savvinov D.D. \& Shumilov Yu.V. (eds.). [Ecology of the Vilyuy River Basin: materials to assess the environmental status]. Yakutsk: Izdatel'stvo "Polygrafist". P.42-63 [in Russian].

Capula M., Cipolla R.M., Corti C. \& Nappi A. 2008. Allochromatic individuals of Podarcis siculus from southern Italy: evidence for high variability in coloration pattern in island and mainland populations from Campania // 6th Symposium on the Lacertids of the Mediterranean Basin. 23-27 June, 2008. Mythimna Lesvos, Greece. P.23-24.

Clusella Trullas S., Terblanche J.S., Blackburn T.M. \& Chown S.L. 2008. Testing the thermal melanism hypothesis: a macrophysiological approach // Functional Ecology. Vol.22. P.232-238.
Doronin I.V. 2012. [On cases of melanism in lizards of the genus Darevskia] // Zoologicheskii Zhurnal. Vol.91. No.11. P.1420-1427 [in Russian, with English summary].

Eizirik E., Yuhki N., Johnson W.E., Menotti-Raymond M., Hannah S.S. \& O'Brien S.J. 2003. Molecular genetics and evolution of melanism in the cat family // Current Biology. Vol.13. No.5. P.448-453.

Evsikov V.I., Nazarova G.G. \& Potapov M.A. 1997. [Genetic-ecological monitoring of the cycling population of the water vole (Arvicola terrestris) in the south of Western Siberia] // Genetika. Vol.33. No.7. P.1133-1143 [in Russian, with English summary].

Galaka B.A. 1967. [On the discovery of a black hare in the Nikolaev Region] // Vestnik Zoologii. No.2. P.80-81 [in Russian].

Gashev S.N. \& Parfenov A.D. 2006. [The collection of "mistakes of nature" in the Zoological Museum of Tyumen State University] // Trudy Gosudarstvennogo Darvinovskogo Muzeya. No.9. P.221-227. [In Russian]

Ge D.Y., Lissovsky A.A., Xia L., Cheng C., Smith A. \& Yang Q. 2012. Reevaluation of several taxa of Chinese lagomorphs (Mammalia: Lagomorpha) described on the basis of pelage phenotype variation // Mammalian Biology. Vol.77. No.2. P.113-123.

Gershenzon S.M. 1946. [The role of natural selection in the distribution and dynamics of melanism in hamsters (Cricetus cricetus L.)] // Zhurnal Obshchei Biologii. Vol.7. No.2. P.97-130 [in Russian].

Heptner V.G., Naumov N.P., Jurgenson P.B., Sludskiy A.A., Chirkova A.F. \& Bannikov A.G. 1967. [Mammals of the Soviet Union. Vol.2. Pt.1. Sea Cows and Carnivora]. Moscow: Vysshaya Shkola. 1014 p. [in Russian].

Hoffmann R.S. \& Smith A.T. 2005. Order Lagomorpha // Wilson D.E. \& Reeder D.M. (eds.). Mammal Species of the World. A Taxonomic and Geographic Reference. 3rd. ed. Vol.1. Baltimore: John Hopkins University Press. P.185-211.

Kawanishi K., Sunquist M.E., Eizirik E., Lynam A.J., Ngoprasert D., Wan Shahruddin W.N., Rayan D.M., Sharma D.S.K. \& Steinmetz R. 2010. Near fixation of melanism in leopards of the Malay Peninsula // Journal of Zoology. Vol.282. No.3. P.201-206.

Kettlewell H.B.D. 1955. Selection experiments on industrial melanism in the Lepidoptera // Heredity. Vol.9. No.3. P.323-342.

Krapivko T.P. 1999. [The case of melanism in the red vole population] // Tezisy Dokladov VI S'ezda Teriologicheskogo Obshchestva. Moscow. P.129 [in Russian].

Kukushkin O.V. 2009. [On some patterns in the distribution of the Lindholm lizard (Sauria, Lacertidae) on the southeastern coast of the Crimea] // Samarskaya Luka: Problemy Regionalnoi i Globalnoi Ekologii. Vol.18. No.1. P.68-75 [in Russian].

Maak R.K. 1886. [The Vilyuy District of the Yakutsk Region]. Saint Petersburg: Typographiya i Khromolithographiya A.Transchelya. 504 p. [in Russian].

Majerus M.E.N. 1998. Melanism: Evolution in Action. New York: Oxford University Press. 388 p.

Majerus M.E. 2009. Industrial melanism in the peppered moth, Biston betularia: an excellent teaching example of Darwinian evolution in action // Evolution: Education and Outreach. Vol.2. No.1. P.63-74. 
Malyshev Yu.S. 2010. [Melanism in the red vole population (Clethrionomys rutilus Pallas) of the Upper Angara Basin] // Baikalskii Zoologicheskii Zhurnal. No.2. P.81-85 [in Russian].

Malyshev Yu.S. 2015. [Detection of melanism in the population of the northern pika (Ochotona hyperborea Pallas) of the Upper Angara Basin] // Baikalskii Zoologicheskii Zhurnal. No.2. P.91-96 [in Russian].

Marshintsev V.K. \& Yagnishev B.S. 2008. [Geological and geochemical features of the Vilyui region and the state of health of its local population] // Savvinov G.N. (ed.). Ekologicheskaya Bezopasnost' Yakutii. Yakutsk: Izdatel'stvo Yakutskogo Nauchnogo Tcentra SO RAN. P.321-338 [in Russian].

Mutsetoni V.M. 1987. [White raven and birds-of-paradise]. Moscow: Lesnaya Promyshlennost'. 136 p. [in Russian].

Ognev S.I. 1940. [The Mammals of the USSR and Adjacent Countries. Vol.4]. Moscow, Leningrad: Izdatel'stvo Akademii Nauk SSSR. 615 p. [in Russian].

Pearson T. 1938. The Tasmanian brush opossum, its distribution and colour varieties // Papers and Proceedings of the Royal Society of Tasmania. P.21-30.

Seidensticker J. \& Lumpkin S. 2006. Cats. New York: Harper Perennial Publ. 218 p.
Sharygin S.A. \& Popov V.N. 2003. [Phenotypic variability and geochemical ecology of some true Crimea lizards] // Aktualnye Problemy Gerpetologii i Toksinologii (Tolyatti). No.6. P.110-116 [in Russian].

Tavrovsky V.A., Egorov O.V., Krivosheev V. G., Popov M.V. \& Labutin Yu.V. 1971. [Mammals of Yakutia]. Moscow: Nauka. 659 p. [in Russian]

Timofeeff-Ressovsky N.W. 1940. Zur Analyse des Polymorphismus bei Adalia bipunctata L. // Biologisches Zentralblatt. Bd.60. No.3-4. S.130-137.

Tuniyev B.S., Orlov N.L., Ananyeva N.B. \& Agasyan A.L. 2009. [Snakes of the Caucasus: Taxonomic Diversity, Distribution, Protection]. Saint Petersburg, Moscow: KMK Scientific Press. 223 p. [in Russian].

Ulmer F.A. 1941. Melanism in the Felidae, with special reference to the genus Lynx // Journal of Mammalogy. Vol.22. No.3. P.285-288.

Vinokurov V.N., Boeskorov G.G., Shchelchkova M.V. \& Duro-Daini A.V. 2017. [Observations on the anomalous cases in the mountain hare (Lepus timidus L.) in Yakutia] // Vestnik Severo-Vostochnogo Federalnogo Universiteta. No.10. P.5-12 [in Russian, with English summary]. 